NBER WORKING PAPER SERIES

\title{
FEES ON FEES IN FUNDS OF FUNDS
}

\author{
Stephen J. Brown \\ William N. Goetzmann \\ Bing Liang \\ Working Paper 9464 \\ http://www.nber.org/papers/w9464
}
NATIONAL BUREAU OF ECONOMIC RESEARCH
1050 Massachusetts Avenue
Cambridge, MA 02138
January 2003

We should like to acknowledge the very constructive comments of the Editor and of an unknown reviewer, as well as the extremely helpful and constructive comments of Edwin Elton, Erol Emed, Martin Gruber, Bruce Grundy, Adriaan Klop, Richard McAloney and Laurens Swinkels, without of course implicating them in any errors of omission or commission that remain. We would also like to thank participants at the 2002 SIRCA Funds Management conference, Sydney and a presentation at Melbourne Business School for helpful comments. The views expressed herein are those of the authors and not necessarily those of the National Bureau of Economic Research.

(C)2003 by Stephen J. Brown, William N. Goetzmann, and Bing Liang. All rights reserved. Short sections of text not to exceed two paragraphs, may be quoted without explicit permission provided that full credit including notice, is given to the source. 
Fees on Fees in Funds of Funds

Stephen J. Brown, William N. Goetzmann, and Bing Liang

NBER Working Paper No. 9463

January 2003

JEL No. G1

\begin{abstract}
Funds of funds are an increasingly popular avenue for hedge fund investment. Despite the increasing interest in hedge funds as an alternative asset class, the high degree of fund specific risk and the lack of transparency may give fiduciaries pause. In addition, many of the most attractive hedge funds are closed to new investment. Funds of funds resolve these issues by providing investors with diversification across manaager styles and professional oversight of fund operations that can provide the necessary degree of due diligence. In addition, many such funds hold shares in hedge funds otherwise closed to new investment allowing smaller investors access to the most sought-after managers. However, the diversification, oversight and access comes at the cost of a multiplication of fees paid by the investor. One would expect that the information advantage of funds of funds would more than compensate investors for these fees. Unfortunately, individual hedge funds dominate fund of funds on an after-fee return or Sharpe ratio basis. In this paper we argue that the disappointing after-fee performance of some fund of funds may be explained by the nature of this fee arrangement. Fund of funds providers pass on individual hedge fund incentive fees in the form of after-fee returns, although they are in a better position to hedge these fees than are their investors. We examine a new fee arrangement emerging in the industry that may provide better incentives at a lower cost to investors in these funds.
\end{abstract}

Stephen J. Brown

NYU Stern School of Business

44 West $4^{\text {th }}$ Street

New York, NY 10012-1126

sbrown@stern.nyu.edu

Bing Liang

Case Western Reserve University

Weatherhead School of Management

10900 Euclid Avenue

Department of Banking and Finance

Cleveland, OH 44106-7235

bx14@po.cwru.edu
William N. Goetzmann

Yale School of Management

International Center for Finance

Box 208200

135 Prospect Street

New Haven, CT 06520-8200

and NBER

william.goetzmann@yale.edu 


\section{Fees on Fees in Funds of Funds}

Abstract: Funds of funds are an increasingly popular avenue for hedge fund investment. Despite the increasing interest in hedge funds as an alternative asset class, the high degree of fund specific risk and the lack of transparency may give fiduciaries pause. In addition, many of the most attractive hedge funds are closed to new investment. Funds of funds resolve these issues by providing investors with diversification across manager styles and professional oversight of fund operations that can provide the necessary degree of due diligence. In addition, many such funds hold shares in hedge funds otherwise closed to new investment allowing smaller investors access to the most sought-after managers. However, the diversification, oversight and access comes at the cost of a multiplication of the fees paid by the investor. One would expect that the information advantage of funds of funds would more than compensate investors for these fees. Unfortunately, individual hedge funds dominate fund of funds on an after-fee return or Sharpe ratio basis. In this paper we argue that the disappointing after-fee performance of some fund of funds may be explained by the nature of this fee arrangement. Fund of funds providers pass on individual hedge fund incentive fees in the form of after-fee returns, although they are in a better position to hedge these fees than are their investors. We examine a new fee arrangement emerging in the industry that may provide better incentives at a lower cost to investors in these funds.

\section{Introduction}

Despite the growing interest in hedge funds, it is difficult for many individual and institutional investors to participate in this area of the market. Minimum wealth levels and sophisticated investor requirements constrain many small investors. Legal limits on the number of U.S. investors allowed in hedge funds effectively place a lower bound on the size of investment most hedge fund managers will accept. In fact, many otherwise attractive hedge funds are closed to new investment. For those open to new investment, the minimum unit size is usually quite substantial. Thus, even for smaller institutions and endowments it can be expensive and in many cases impractical to invest in hedge funds with a prudent degree of diversification. Unlike registered investment companies, hedge funds are not required - indeed by most legal interpretations not allowed to publically disclose performance and holdings information that might be construed as solicitation materials. This has the unfortunate effect of making it more difficult for potential hedge fund investors to evaluate managers on a comparative basis. In 
addition, little public information exists about fund operations and their holdings and investment strategies are typically undisclosed for strategic reasons.

Funds of funds (sometimes in this context referred to as "funds-of-hedge funds") [FOF] are financial intermediaries established to address several of these issues. They are hedge funds themselves which hold shares in other investment companies and charge a fee for doing so. According to Tremont TASS (Europe) Limited (hereafter TASS), a London-based information and research company dedicated to the alternative investment industry, FOFs comprise a significant proportion of the hedge fund business. As of March 2000, the TASS hedge fund database contains 2,104 hedge funds, including 1,330 survived funds and 774 dissolved funds. The total assets under management are about $\$ 198$ billion. According to TASS, there are 328 funds that are classified as FOFs, comparing to 1,442 regular hedge funds. ${ }^{1}$ The typical FOF invests in a range of hedge funds. They allow investors to participate in hedge fund investments that are otherwise closed, and allow for diversification across hedge funds. They also provide professional management services and access to information that would be difficult or expensive to obtain on a fund by fund basis by the investor. For this reason, some authors argue that the appropriate index of hedge fund return is indeed the return on well managed FOFs. ${ }^{2}$

However, the major disadvantage of this arrangement is the cost to the investor. In addition to the fees charged by the FOF, they effectively pass on to the investor all fees charged by the constituent funds, since, in most cases, they report their raw returns after all of the underlying manager fees are paid. A common concern among practitioners is that this double fee

\footnotetext{
${ }^{1}$ The remaining 334 funds are not otherwise classified by TASS.

${ }^{2}$ Fung and Hsieh(2000).
} 
arrangement might induce FOF managers to invest in unduly risky hedge funds to ensure that the returns gross of fees are sufficiently large to absorb the FOF fees charged. ${ }^{3}$ While it is true that the FOF structure allows for diversification and hence reduction of risk at the fund level, there is an often overlooked cost to this diversification. The more diversified the fund is, the greater the likelihood that the investor will incur an incentive fee on one or more of the constituent managers, regardless of overall FOF performance. In fact there is a significant probability that the incentive fee will be so large that it absorbs all of the annual fund return.

The fact that FOFs incur incentive fees is not of itself a reason to avoid FOF investments. After all, an informed investor who invests in the underlying hedge funds would incur the same fees. However, such an investor would be able to hedge the incentive fee component at least to the extent that they could understand the underlying hedge fund positions. The problem arises asesult of the fact that investors choose to invest in FOFs precisely because they lack this necessary information. They are willing to pay management fees to FOFs to acquire information that is expensive or otherwise unavailable to them on an individual basis. On the other hand, FOFs are not obliged under current regulations to provide investors with current information on positions they take in constituent funds, let alone the positions taken by the underlying hedge funds. For this reason, FOF investors cannot hedge the incentive fees that are passed on by the FOF. The expected value of this unhedged fee then becomes a deadweight cost that impairs the performance of FOF investments. We document that this fee can be quite substantial, and is one reason for the relatively poor performance experience of most FOFs.

The extent to which agents can hedge incentive fee contracts is of course a central issue

${ }^{3}$ See for example http://www.planethedgefund.com/hedgeqa/questionpages/q14.php3. 
in the emerging literature on management incentives in the investment management industry. Most researchers assume (for example, Carpenter 2000) that managers cannot hedge their incentive contracts. Ability to hedge the contract converts the incentive feature into just another form of manager compensation unrelated to performance. In many cases this constraint is descriptively accurate. Money managers are frequently constrained from trading on their own account where such trading can represent a clear conflict of interest. On the other hand, FOF managers face no such institutional constraint, and are compensated to acquire the very information necessary to hedge incentive contracts, both their own and those of the funds they invest in. If the FOF provider cannot hedge the incentive fee component of returns, then perhaps they lack the competence to be fund managers in the first place.

What emerges from this theoretical literature is the implication that if incentive fees are effective, they will be effective if at all at the hedge fund or individual manager level but not at the FOF level. Our empirical results provide support for this conclusion. Consistent with the results presented in Elton and Gruber (2002) for mutual funds, we find evidence that incentive fees are associated with higher risk-adjusted performance for hedge funds. Some funds charge no incentive fees, while other funds charge fees that are 20 percent or more of the return above benchmark. Hedge fund Sharpe ratios bear a significant and positive relationship with the rate at which incentive fees are charged. The same result does not follow for FOFs. Here the rate at which incentive fees are charged is unrelated to performance.

What remains a mystery is why FOFs do not hedge individual hedge fund incentive fees, given that they have the motive and opportunity to do so. By doing so they would eliminate a deadweight cost which we show can be quite substantial, at least based on information from 1995 to 2000. Sophisticated investors are beginning to require FOF providers to absorb 
individual hedge fund fees in return for a higher management fee/incentive fee structure at the FOF level. Our results indicate why this is the case.

FOFs represent an interesting special case of the delegated fund management problem posed by Sharpe in his Presidential Address (Sharpe 1981). He was concerned about the problem faced by an overall fund manager (the FOF provider in this instance) who has to allocate funds among a set of independent fund managers with their own objectives and constraints, where there is only limited information available about the opportunity set faced by the individual manager. The FOF example is interesting as an extreme example of this delegated management problem where the FOF provider is paid substantial management fees to acquire information about the investment decisions of the individual managers. These fees reflect the value placed on the improvement in portfolio choices made as a result. They do not however compensate for the deadweight cost associated with inefficient or non existent hedging of individual incentive fees. The fact that competitive pressures are only now beginning to force FOF providers to hedge individual fund incentive fees suggests that this may be an industry in its infancy.

In the remainder of this paper we describe the data used in the study and then in Section 3 document some of the differences between FOFs and the hedge funds in which they invest, not only in their observed characteristics, but also in the extent to which fee structures are related to performance. In Section 4 we provide some examples that give an illustrative order of magnitude on incentive fees and the deadweight cost associated with not hedging them. In Section 5 we document an emerging fee structure arrangement that may yield superior after-fee returns and superior incentives for FOF managers. Section 6 concludes.

\section{Data}


We use the dataset provided by TASS which contains data on after-fee returns for the period February 1989 through March 2000. The dataset also includes the TASS "graveyard" - funds that existed in the period 1994 to the present but which have since dropped from the active fund sample. The last three months of data were excluded because of concerns about late reporting by a subset of hedge funds covered in the report. TASS also provides data on the considerable variety of fee structures used by hedge funds, including management and incentive fees. Among other things, it documents performance benchmarks used in calculating fees, redemption charges, and other expenses payable by the investor. An accompanying file of notes records the many exceptions to standard fee structures. For example, in a number of cases, the incentive fee charged per dollar return in excess of the performance benchmark increases as a function of the positive performance realized by the fund in excess of benchmark. In most cases, this performance benchmark is zero, but in many cases the fund has to earn a fixed return typically 10 percent, and sometimes even as high as 30 or even 50 percent before incentive fees are charged. In other examples, the fund has to earn a return in excess of the Treasury Bill rate, LIBOR or some other performance index benchmark. Highwatermark provisions typically require fund managers to make up losses relative to their benchmark from previous years before earning an incentive fee in the current period. This provision makes the valuation of the hedge fund management contract an interesting challenge (c.f. Goetzmann, Ingersoll and Ross, 1997). To examine the relationship between fee structures and after-fee return, we use the total after-fee return provided by TASS for all hedge funds it surveys. However, to study the magnitude of incentive fees and to examine their impact on return we need some measure of before-fee returns. While the TASS database, in common with other hedge fund data providers, gives only returns after fees have been paid, it is possible using the fee schedules provided by 
TASS to calculate an approximation of the before-fee return. ${ }^{4}$ The resulting before-fee numbers are an approximation for several reasons. In the first place, there is some variation in when fees are computed and charged. In the overwhelming majority of cases, the fees are calculated on an annual basis, although there are a few instances where the fees are computed and payable on a quarterly basis, and one instance where fees are charged on the basis of a five-year return period. We assume for simplicity that all fees are computed and payable on an annual cycle. For this reason, in the results that use before-fee returns, we are forced to exclude funds for which we have less than one full calendar year of data. In addition, a minority of funds charge management fees that vary with the size of account. We also ignore this qualification in our before-fee results. Since we assume that highwatermark provisions are met as of the first year of survivorship free data (1994), we impart an upward bias in 1995 calculated incentives. ${ }^{5}$ Finally, there were 12 cases where the algorithm used to compute before-fee returns failed, and for this reason those funds were excluded from the before-fee analysis. ${ }^{6}$

${ }^{4}$ There is no uniformity in fee schedules across funds. A wide variety of benchmarks and highwatermark provisions are commonly in use, and in some cases, incentive fees are in fact a nonlinear function of return. In a small minority of cases these fees are dependent on the size of the investment with a discount offered for large fund holders. The fee schedules used to construct before-fee returns were determined from a close reading of the Notes section of the TASS database dated March 2000. While the benchmark variation and nonlinearity of fee schedules is accounted for, it is not possible to adjust for variations by size of investment.

${ }^{5}$ Brown, Goetzmann and Park (2001) show that not meeting the highwatermark provision two years in a row is a good predictor of fund failure and hence departure from our database in later years of our sample.

${ }^{6}$ The algorithm used to compute before-fee returns is as follows. For each year, the annual incentive fee was computed on the basis of an estimate of prior year before-fee returns. The estimate of before-fee returns is updated by adding back to the after-fee returns for each month, one twelfth of the annual fee expressed as a fraction of the prior month value accumulated at the estimated before-fee return. Convergence is achieved when successive estimates of the before-fee return differ in absolute value by less than $10^{-11}$ within 35 iterations. 


\section{Characteristics and performance of fund of funds}

Table 1 provides the basic statistics for FOFs and hedge funds. As expected, FOFs provide significant diversification potential. The notion that FOFs are unduly risky is not supported in the data. Not only do FOFs reduce by a third the standard deviation of monthly hedge fund returns, but they also significantly reduce the value at risk of hedge fund investment. ${ }^{7}$ This value at risk result is particularly significant, as it is based on an examination of returns after all fees are paid. A fiduciary who is primarily concerned about the downside risk associated with hedge fund investment should seriously consider a FOF vehicle.

However, as noted before, diversification is not the only reason why investors invest in FOFs. These instruments provide the investor with professional management and due diligence services, as well as access to otherwise closed funds. One would expect that investors would be prepared to pay for these services, but that the additional return would compensate them for any fees charged. Unfortunately that is not the case. The average monthly after-fee return for FOFs is $0.86 \%$, only a little more than half of the $1.38 \%$ return for hedge funds over the same period of time. While some of this discrepancy may be due to some extreme outliers (the median monthly after-fee return for FOFs is $.79 \%$ as opposed to $1.05 \%$ for hedge funds), the difference is economically significant. This discrepancy has been noted in the finance literature. Fung and Hsieh (2000), for example, find that at least part of the reported under-performance of FOFs may

This algorithm failed in only twelve cases. These cases corresponded to short-lived funds with extraordinary volatility of returns.

${ }^{7}$ As indicated in Table 1, the lower 5 percent fractile of the empirical distribution of monthly fund returns is two percentage points higher for FOFs. This difference is significant at the 1 percent level. 
be attributed to survivorship which effectively biases upwards the reported performance of individual hedge funds. FOFs which actually hold the shares of hedge funds when they become available, and experience the monetary losses when they are incurred, perhaps better represent the actual investment performance of the hedge fund investor, and thus are perhaps a better index of aggregate hedge fund performance. We are of course sympathetic to the survivorship story - particularly since the use of annual returns still includes some conditioning on survival. For this reason, it is essential to include returns on all defunct or non-reporting funds contained in the TASS graveyard file. The survival issues are important, but it is also useful to focus on the role of FOF fees as an additional explanation for the poor relative performance of FOFs.

Table 1 documents some additional differences between hedge funds and FOFs. On average, FOFs are smaller in size than the hedge funds in which they invest. They manage $\$ 64$ million in assets on average, compared to $\$ 123$ million for the average hedge fund in the sample. Another difference is that fewer fund managers have a stake in their own funds. While 56 percent of FOF managers have a personal investment in their own funds, the corresponding percentage is 65 percent for hedge fund managers. The difference is significant at the $1 \%$ level. Probably the most interesting result in Table 1 is the difference in management and incentive fees between the two fund groups. The median management fee for FOFs is $1.5 \%$, comparing to $1 \%$ for hedge funds, reflecting the nature of the two-tier fee structure of FOFs. Both FOFs and hedge funds typically charge an incentive fee expressed as a percentage of fund returns over a specified benchmark. In addition both FOFs and hedge funds are typically required to make up for past losses before incentive fees may be charged (the "highwatermark provision"). However, the median incentive fee charged by FOFs is only $10 \%$, comparing to $20 \%$ for hedge funds. The differences in fees reflect the different incentives of FOF managers and hedge fund managers. 
Since FOFs provide significant diversification potential, an investor might expect that the reward to volatility ratio is higher for FOFs than it is for the average hedge fund. In Table 2 we report the average Sharpe ratio on an annual basis for FOFs and hedge funds during the six-year period from 1994 to 1999, the period for which we have survivorship-free data. FOFs offer consistently lower Sharpe ratios, as well as lower average returns in many of the years documented. The implication is that direct investment in individual hedge funds, on average yields a higher reward to variability ratio - and that a levered position in FOFs that matched the expected return of the hedge fund sample is in fact riskier at least in terms of standard deviation. The data suggest either that FOF managers have not done a particularly good job at selecting superior hedge funds, or that the fees they charge more than capture the benefits they deliver. ${ }^{8}$

A cross-sectional analysis of the FOF universe is perhaps more instructive, since it allows us to compare managers that are subject to similar survival conditioning and similar evaluation by the investment community. In Table 3 we examine the extent to which FOF fees are related to performance. The FOF fee structure can be broken down into the incentive fee that gives the rate at which incentive fees are charged, and the management fees which represent the fixed percentage of assets under management used to pay for management expenses and other

${ }^{8}$ Differences in Sharpe ratios do not necessarily indicate differences in skill where returns are left-skewed due to inclusion of derivative securities or option-like trading strategies (Goetzmann, Ingersoll, Spiegel and Welch (2002)). However, in this case FOF returns are actually more left skewed (average skewness -.307) than are individual fund returns (average skewness -.126) and the difference is significant at the 1 percent level. For this reason it is difficult to attribute the higher Sharpe ratio of individual funds to increased negative skewness in the distribution of returns. This argument does not affect cross sectional results reported later in the paper. Lo (2002) advises care in the interpretation of hedge fund Sharpe ratios where positive autocorrelation in monthly returns can cause an upward bias in the estimated ratios. While the average first and second autocorrelation coefficients are significant (albeit smaller in magnitude than for the sample that Lo (2002) reports), they are significantly higher for the FOF sample. Hence we cannot attribute a lower FOF average Sharpe ratio to an autocorrelation artefact. 
fees. As noted before, there is a rich variety of ways in which the incentive fee benchmark is specified, but this variation is not reflected in Table 3 .

A linear regression of after-fee performance on the rate at which incentive fees are charged finds no connection between the two. Cross sectionally, it appears on the other hand that FOF managers that charge higher management fees achieve a lower risk adjusted return. Interestingly, no such relationship exists for hedge funds taken as a whole. It appears that the management fee for the typical FOF company is a deadweight load that has the effect of simply reducing after-fee return. On the other hand, the rate at which incentive fees are charged does have a significant positive relationship with risk adjusted returns for individual hedge funds. The conclusion is clear. While the fee structure appears to provide an appropriate incentive for hedge fund managers, it does not appear to motivate FOF managers to achieve superior returns. It is important to note that the table shows the relationship between the rate of fees charged and current performance in the cross section of funds. It does not test the proposition that high current fees are associated with higher future performance. This is a very interesting issue for future research.

\section{An example}

The FOF charges incentive fees based on the after-fee return to the individual hedge fund. This implies that the ultimate investor may end up paying incentive fees regardless of how well or poorly the FOF actually performs. To see how this might happen, consider a very simple numerical example given in Table 4. In this example we assume for simplicity that all funds charge a standard 20 percent incentive fee over a zero benchmark with no fixed management fee. With just three funds, the first and second funds may perform well, earning 20 and 40 percent 
respectively. However, if the third fund performs sufficiently poorly, the overall fund may end up losing money. In this example, the before-fee return is -5 percent. However, there are incentive fees owing to the first two funds, amounting in total to 4 percent of the assets at the start of the year. This 4 percent represents an additional fee that is subtracted from returns in calculating the after-fee returns. In this example, the after-fee return correspond to a loss of nine percent. While the investor escapes the FOF incentive fee because of a negative portfolio return, he or she must pay the incentive fees to the underlying managers. While an accounting of the incentive fees of the underlying managers is generally not explicitly provided to the FOF investor, the fees are never-the-less genuine monetary expenses that the intermediary institution pays and passes through to the client.

The example given in Table 4 is obviously an extreme example meant to illustrate the point. Under realistic circumstances, can it ever happen that an investor is liable for incentive fees when the fund as a whole loses money? Unfortunately, the answer is yes. To examine in some greater detail the relationship between fees and returns, we consider an example where FOF managers provide diversification services but, consistent with the results in Table 1, do not contribute to returns. We calculate the historical returns on FOFs from 1995 to 2000 constructed by choosing the constituent funds at random from the set of funds in business at the beginning of the period. As funds leave the sample, they are replaced by other funds in business at the time. We perform this exercise first for FOFs comprising only one fund, and then we consider what happens when we add more funds to the FOF. Stating returns on the underlying managers on a before-fee basis allows us to decompose the return to the FOF investor into the portion attributable to the underlying portfolio, the portion attributable to underlying manager fees, and the portion attributable to the FOF fees. 
In Figure 1 we take the first case, where the hypothetical funds consist of only one fund. The data corresponds to all 811 hedge funds which according to TASS were operating at the start of 1995 and for which we were able to compute before-fee returns, excluding all FOFs. We then compute the realized annual returns to 811 hypothetical FOFs each investing in one and only one of these funds. ${ }^{9}$ In this example, the incentive fees charged by the funds and the highwatermark benchmark before which fees are paid correspond to the actual fees and benchmarks listed by TASS for each of the funds. The hypothetical FOFs charge a 10 percent incentive fee over and above a zero benchmark. The solid line gives the relationship between returns and incentive fees suggested by an incentive fee schedule where the FOFs charge an incentive fee on top of the 20 percent of return fee charged by the individual fund.${ }^{10}$ Funds may actually charge less than this, either because they have more modest incentive fee schedules, or because of the requirement that they earn back past losses before they are awarded this incentive fee (the highwatermark provision). Most funds employ a zero benchmark before they are entitled to an incentive fee, while some have a fixed benchmark or a benchmark based on an index return (T Bill rate, LIBOR or other benchmark).

We see that there is a great variation in realized before-fee return across years and across funds, ranging from almost an entire loss, to a possible 441 percent gain. It is important to note that such extreme returns may be on a very small base. The largest return recorded in the

${ }^{9}$ To deal with the fact that not all 811 funds survived the entire period we assume that the FOF manager was astute enough to withdraw funds the month prior to the fund leaving the database, and reinvest the proceeds in another hedge fund in operation at that time. This will of course typically overstate the realized returns, as funds fail without prior warning, and in many cases there are restrictions that prevent such rapid withdrawals.

${ }^{10}$ These incentive fees and the benchmark correspond to the median numbers recorded in the TASS database. 
database did not generate an incentive fee, as in this particular case the fund lost $95.6 \%$ of its value in the prior year. The fund did not receive an incentive fee that year, as even a quadrupling of value was insufficient to erase the prior year losses. As noted above, the losses could even be greater, as we exclude from our database funds immediately prior to failure. One of the major attractions of FOFs is that they provide the investor with the opportunity to diversify and hence alleviate this volatility.

In Figure 2 we consider the same period of data, for a set of 811 hypothetical funds equally invested as of the beginning of 1995 in five hedge funds chosen entirely randomly from the set of available funds. Diversification clearly decreases the incidence of extreme returns, both negative and positive. At the same time however, diversification appears to be costly. The more diversified the FOF, the greater is the chance that at least one of the funds generates an incentive fee to an underlying manager. Since the FOF provides after-fee returns to the investor, the investor may in effect be paying an incentive fee regardless of the performance of the overall fund. In fact, we find that the investor may actually end up paying incentive fees to the underlying managers that exceed the annual return on the fund. In the Figure we highlight 9.81 percent of fund/year returns for which this is the case. Comparing Figures 1 and 2 we find that diversifying into as few as five funds can substantially increase the probability of paying fees on negative returns. When the fund earns less than 20 percent before fees, the additional fees can amount to between to two to three percent of assets at the start of the year. It is important to note that these fees do not accrue to the FOF provider when the fund as a whole loses money. Rather, these are incentive fees paid to individual funds and are passed on to investors in the form of after-fee returns through the FOF vehicle. When we consider a case of ten funds chosen at random, the FOF investor almost always has to pay an incentive fee to an underlying manager. 
In fact out of 4,055 fund years, there was only one case in which no incentive fees were charged, despite fund returns falling as low as -30 percent per annum on a before-fee basis. In this worst case outcome, the investor would actually end up paying a 2.3 percent incentive fee! Funds that lose money on a before-fee basis lose on average an additional 1.1 percent on an after-fee basis accounting for incentive fees paid, and this additional burden can rise to as much as 3.4 percent.

The fact that investors end up paying incentive fees when the FOF loses money is of course not a criticism of the FOF diversification strategy. Individual investors investing in the same funds would suffer the same fees, and diversification does not increase the fee burden. To take a very simple example, suppose a FOF were to be fully invested in a hedge fund with a 2:1 leveraged position in a S\&P 500 contract. Again, for simplicity assume that all assets are lognormally distributed with zero drift and a zero riskfree rate. The investor would pay an incentive fee half of the time. The expected value of this fee is increasing in volatility and would equal 4.2 percent if annual volatility is 40 percent. ${ }^{11}$ On the other hand, if the fund invested half of the funds in a hedge fund comprising a leveraged S\&P 500 position, and half of the funds in a fund that maintained an equivalent short position, then the investor would pay half of the incentive fee all of the time. The expected value of both the incentive fee and of total returns is identical in both cases.

The difference of course is that the individual informed investor can potentially hedge the incentive fees charged by the hedge fund, whereas they may choose to invest in the FOF precisely when the necessary information for hedging purposes is unavailable or expensive to

${ }^{11}$ For an initial fund value $S=1$, the expected fee is given as $.2(\mathrm{E}(\mathrm{S} \mid \mathrm{S}>1)-1) \operatorname{Pr}(\mathrm{S}>1)$. If the annual return on the fund is lognormal with zero drift and volatility .2, the conditional expectation $\mathrm{E}(\mathrm{S} \mid \mathrm{S}>1$ ) is 1.42 (Johnson and Kotz (1970) p.129), and the expected fee is $4.2 \%$ of initial fund value. 
acquire. In the simplified fact situation given above, the Black-Scholes value of the incentive fee call option is 3.2 percent. The difference (in this example, one percent) is always positive and an increasing function of volatility, and amounts to a significant deadweight cost associated with not hedging the underlying hedge fund incentive fees. In a more realistic setting, the magnitude of this deadweight cost will depend in a complicated way on the capital market assumptions, the incentive fee, benchmark and highwatermark provisions. Taking the historical fund volatilities

from the TASS database, the precise incentive fee arrangements, benchmark and highwatermark provisions from the same source, the deadweight cost estimated for each of the years 1995 through 1999 was positive and substantial (Table 5). This is of course an overstatement of the potential gains from hedging. Certain hedge fund strategies (true market neutral strategies for example) would generate incentive fees that would be difficult to hedge. In cases such as these the FOF manager might choose to hedge the underlying hedge fund incentive fees by charging an incentive fee based on overall fund performance.

\section{Alternative fee structures: A modest proposal}

The results reported in Tables 2 and 3 suggest that far from encouraging FOF managers to seek out higher risk adjusted returns, the current incentive fee on fee arrangements represent a deadweight cost passed on to investors, payable whether or not the fund as a whole makes a positive return, consistent with the example given in Section 4. Since the results in Table 5 indicate that a FOF provider can improve returns by 200 basis points or more by appropriately hedging underlying incentive fees, the puzzle is why they do not absorb (and hedge) these fees. Part of the reason may be the difficulty associated with hedging the fees, but part of the reason may appear to be historical. FOF arrangements appear to have grown out of retail brokerage 
wrap accounts where fee on fee arrangements are very common.

An alternative arrangement that is currently gaining favor would have the FOF manager absorb the individual fund incentive fees in return for a higher FOF management fee and/or incentive fee structure ${ }^{12}$. Essentially, the FOF provider would be long a single incentive fee option and short a variety of smaller incentive fees charged by the individual hedge funds. Appropriately hedged, the cost of such a plan may be quite modest amounting to perhaps no more than 50 basis points, which would then be passed on to the FOF investor as an additional management fee. ${ }^{13}$ Indeed, it is the practice elsewhere in the funds management business for the fund management company to absorb fees and expenses in return for a fee charged at the fund level. Mutual funds for instance, frequently compensate money managers employed by them

\footnotetext{
${ }^{12}$ As of 2000, there was only one FOF in the TASS survey, Commodities Corporation International plc (a Dublin based commodities trader) which offered to absorb incentive fees of the funds under its management in the event that the fund as a whole lost money. One large European pension fund (in private communication) explains that its initial FOF contract requires the FOF to absorb individual hedge fund incentive fees. All of the terms of a typical FOF contract are typically negotiable.

${ }^{13}$ Take the simple case where a FOF provider charges a 20 percent incentive fee on returns in excess of the annual Treasury Bill rate, in return for which the fund absorbs any and all similar incentive fees charged by the constituent funds. The fund is short a portfolio of $k \times p$ call contracts where $k$ is the number of funds in the FOF, and $p$ is the incentive fee for each (in this case, 20 percent), where the exercise price for each call is equal to the future value of the beginning of year fund value at the riskless rate of interest. It is long $p$ calls on a portfolio consisting of $k$ funds. Rearranging the Black Scholes formula, the net cost is positive and depends only on the volatility of the original funds and the extent to which diversification reduces that volatility. The formula is $2 p\left(\mathrm{~N}\left[\frac{\sigma_{0}}{2}\right]-\mathrm{N}\left[\frac{\sigma_{1}}{2}\right]\right)$ for time to maturity $\tau$ one year, $S=1$ and $K=S e^{r \tau}$, where $\sigma_{0}$ is the volatility of the $k$ underlying funds, and $\sigma_{1}$ is the volatility of the portfolio of those funds. For the data considered in Section 2, the median fund had a volatility of 17.1 percent. A five fund portfolio reduces the median volatility by 66.4 percent. As a result, the cost is calculated as 0.46 percent of the initial fund value. This is certainly much smaller than the more than two percent of fund value deadweight cost that the existing unhedged fee arrangement penalizes FOF investors.
} 
using annual bonuses and other forms of performance related compensation. These incentive fees are then considered part of the management expenses that are passed on to investors in the form of a management fee computed on the basis of a flat percentage of the assets under management. ${ }^{14}$ Very rarely do mutual funds charge incentive based fees, and SEC guidelines require that any such fees be symmetric in nature. ${ }^{15}$ The very prevalence of this type of arrangement suggests the conjecture that it may in fact resolve a number of the agency issues that arise in the context of fund management.

\section{Conclusion}

Despite the popularity of hedge funds as an alternative asset class, the high degree of fund specific risk and the lack of transparency give most reasonable fiduciaries pause. In addition, many of the most attractive hedge funds are closed to new investment. FOFs resolve these issues by providing investors with an appropriate degree of diversification and professional management that can provide the necessary degree of due diligence. In addition, many such funds hold shares in hedge funds otherwise closed to new investment. The chief disadvantage of FOFs is the high fees that are typically charged, with an incentive fee component that may under certain circumstances exceed the realized return on the fund. In addition to the fees charged by the FOF, the FOF typically passes on to the investor all fees charged by the constituent funds in the form of after-fee returns.

${ }^{14}$ Carpenter(2000) describes the consequences of these manager incentive payments on their risk taking behaviors.

${ }^{15}$ Incentive fees are relatively new to the mutual fund industry, and are discussed in Elton and Gruber (2002) 
As we note, one of the principal advantages of the FOF arrangement is that it allows for diversification. But the more diversified the fund is, the greater the likelihood that the investor will incur an incentive fee regardless of overall fund performance. In fact there is a significant probability that the incentive fee will be so large that it absorbs all of the annual fund return. The fact that investors end up paying incentive fees when the FOF loses money is of course not a criticism of the FOF diversification strategy. Individual investors investing in the same funds would suffer the same fees, and diversification does not increase the fee burden as an informed investor would face the same fees if they diversified on their own account. The problem arises because investors lack information necessary to hedge incentive fees charged by the underlying hedge funds and passed on to the investor through the FOF in the form of after-fee returns. This inability to hedge underlying incentive fees represents a deadweight cost that may tend to explain the relatively poor historical performance of FOFs relative to the hedge funds in which they invest. This cost arises because the ultimate investor, not the FOF manager, bears the cost of incentive fees incurred whether or not the overall fund makes money. In addition, the data does not indicate that the current incentive fee on fee arrangement leads to superior returns. An emerging alternative arrangement that is in fact common in other areas of the investment management business would have the FOF absorb the individual incentive fees generated by individual managers. An incentive fee at the FOF level would appropriately incentivize the FOF manager and at the same time subsidize the costs of absorbing the individual fund fees. Appropriately hedged, such a fee structure would lead to a very modest increase in the flat management fee changed by the FOF provider. 


\section{References}

Brown, Stephen, William Goetzmann and James Park. 2001 "Careers and survival: Competition and risk in the hedge fund and CTA industry," Journal of Finance 61, 1869-1886.

Carpenter, Jennifer. 2000 Does option compensation increase managerial risk appetite, Journal of Finance 55, 2311-2331.

Elton, Edwin and Martin Gruber. 2002 Incentive fees and mutual funds, forthcoming Journal of Finance.

Fung, William and David Hsieh, 1997, "Survivorship bias and investment style in the returns of CTAs: the information content of performance track records, " Journal of Portfolio Management, 24, 30-41.

Fung, William and David A. Hsieh. 2000 "Performance characteristics of hedge funds and commodity funds: Natural vs. spurious biases," Journal of Financial and Quantitative Analysis, v35(3,Sep), 291-307.

Goetzmann, William N., Jonathan Ingersoll, Jr. and Stephen A. Ross, 1997, "High water marks and hedge fund management contracts," Forthcoming, The Journal of Finance.

Goetzmann, William, Jonathan Ingersoll, Matthew Spiegel and Ivo Welch. 2002 "Sharpening Sharpe ratios" Yale ICF Working Paper No. 02-08 http://papers.ssrn.com/sol3/papers.cfm?abstract id=302815

Henriksson, R. D., and R. C. Merton, 1981 "On Market Timing and Investment Performance. II. Statistical Procedures for Evaluating Forecasting Skills”. Journal of Business 54(4), 513-533.

Johnson, N. L. and S. Kotz, 1970 Continuous Univariate Distributions - 1 Boston: Houghton Mifflin Company.

Lo, A., 2002 “The statistics of Sharpe ratios”, Financial Analysts Journal (July/August), 36-52.

Park, J. and Staum, J., 1999 "Fund of fund diversification: How much is enough?", The Journal of Alternative Investments, Winter 1999. 
Sharpe, W., 1981 Decentralized Investment Management. The Journal of Finance 36, 217-234.

Spurgin, R. B., 2001 How to game your Sharpe ratio. The Journal of Alternative Investments (winter) 4 (3): 38-46. 


\section{Table 1: Descriptive Statistics of Fund of Funds and Hedge Funds}

Data is from Tremont TASS (Europe) Limited (TASS). There are 2,104 hedge funds, including 1,330 survived funds and 774 dissolved funds as of March 2001. There are 328 funds of funds and 1,442 hedge funds. 260 out of 328 funds of funds are live funds while 68 (or 20.7\%) are dissolved. In contrast, 1,063 out of 1,442 hedge funds are live funds while 379 (or 26.3\%) are dissolved. Assets, minimum investments, and minimum hold amounts are in millions of dollars.

Fund of Funds (FOF) Hedge Funds (HF)

\begin{tabular}{|c|c|c|c|c|c|c|c|}
\hline Variable & $\begin{array}{l}\text { Number } \\
\text { of cases }\end{array}$ & Mean & $\begin{array}{l}\text { Standard } \\
\text { deviation }\end{array}$ & $\begin{array}{l}\text { Number } \\
\text { of cases }\end{array}$ & Mean & $\begin{array}{l}\text { Standard } \\
\text { deviation }\end{array}$ & $\begin{array}{c}t \text {-value } \\
\text { (FOF-HF) }\end{array}$ \\
\hline Mean return & 328 & $0.86 \%$ & $1.03 \%$ & 1426 & $1.38 \%$ & $2.02 \%$ & $-6.71 * *$ \\
\hline Std. dev. of return & 328 & $3.91 \%$ & $2.86 \%$ & 1425 & $5.74 \%$ & $4.75 \%$ & $-9.09 * *$ \\
\hline Skewness & 328 & -0.31 & 1.04 & 1424 & -0.13 & 1.39 & $-2.66^{* *}$ \\
\hline Kurtosis & 327 & 4.06 & 6.10 & 1423 & 3.79 & 6.52 & 0.71 \\
\hline Lower $5 \%$ fractile & 328 & $-5.26 \%$ & $5.40 \%$ & 1425 & $-7.21 \%$ & $6.90 \%$ & $5.58^{* *}$ \\
\hline $1^{\text {st }}$ Autocorrelation ${ }^{\mathrm{a}}$ & 319 & 0.15 & 0.21 & 1346 & 0.08 & 0.20 & $3.25 * *$ \\
\hline $2^{\text {nd }}$ Autocorrelation ${ }^{\mathrm{a}}$ & 319 & 0.05 & 0.15 & 1346 & -0.01 & 0.16 & $2.80 * *$ \\
\hline $3^{\text {rd }}$ Autocorrelation ${ }^{\mathrm{a}}$ & 319 & -0.03 & 0.12 & 1346 & -0.03 & 0.15 & -1.55 \\
\hline Assets & 325 & $\$ 64.04$ & $\$ 235.55$ & 1416 & $\$ 122.63$ & $\$ 751.51$ & $-2.45^{*}$ \\
\hline Personal investment ${ }^{\mathrm{b}}$ & 327 & 0.56 & 0.50 & 1420 & 0.65 & 0.48 & $-2.96 * *$ \\
\hline Managememnt fee & 328 & 1.68 & $0.86 \%$ & 1442 & 1.45 & $0.90 \%$ & $4.33^{* *}$ \\
\hline Incentive fee & 328 & 9.64 & $8.51 \%$ & 1442 & 17.80 & $6.75 \%$ & $-16.24^{* *}$ \\
\hline Leverage $^{\mathrm{b}}$ & 327 & 0.64 & 0.48 & 1417 & 0.77 & 0.42 & $-4.51 * *$ \\
\hline Age & 328 & 70.57 & 42.14 & 1426 & 57.79 & 48 & $4.97^{* *}$ \\
\hline Notice period & 297 & 34.54 & 52.31 & 1324 & 29.92 & 30 & 1.48 \\
\hline Minimum investment & 319 & $\$ .25$ & $\$ 0.54$ & 1388 & $\$ .78$ & $\$ 0.25$ & $-2.85^{* *}$ \\
\hline Minimum hold & 120 & $\$ .24$ & $\$ 0.78$ & 585 & $\$ .55$ & $\$ 0.25$ & $-3.08 * *$ \\
\hline
\end{tabular}

${ }^{\mathrm{a}}$ Autocorrelation coefficients are estimated for funds with a minimum of one year of continuous data.

${ }^{\mathrm{b}}$ Dummy variables: 1 if yes and 0 if no.

$* *$ Significant at $1 \%$ level.

*Significant at 5\% level. 


\section{Table 2: Performance and Risk: Fund of Funds versus Hedge Funds}

The table reports the annual average return for the funds in the TASS database including defunct funds after 1994. The cross-sectional standard deviation of mean returns is reported in the third column. The average Sharpe ratio for funds is based on calculations for the corresponding year of data, and is recorded in the fourth column. Column 8 reports a t-test of the difference in the mean return for hedge funds vs. funds of funds. Column 9 reports the results of a t-test for differences in the mean Sharpe ratio for hedge funds vs. funds of funds.

\begin{tabular}{|c|c|c|c|c|c|c|c|c|}
\hline & \multicolumn{3}{|c|}{ Fund of Funds } & \multicolumn{3}{|c|}{ Hedge Funds } & \multirow{2}{*}{$\begin{array}{c}t \text {-value } \\
\text { Return } \\
\text { (FOF-HF) }\end{array}$} & \multirow{2}{*}{$\begin{array}{c}t \text {-value } \\
\text { Sharpe } \\
\text { (FOF-HF) }\end{array}$} \\
\hline Year & $\begin{array}{l}\text { Mean } \\
\text { Return }\end{array}$ & $\begin{array}{l}\text { Median } \\
\text { Return }\end{array}$ & $\begin{array}{c}\text { Sharpe } \\
\text { Ratio }\end{array}$ & $\begin{array}{l}\text { Mean } \\
\text { Return }\end{array}$ & $\begin{array}{l}\text { Median } \\
\text { Return }\end{array}$ & $\begin{array}{c}\text { Sharpe } \\
\text { Ratio }\end{array}$ & & \\
\hline 1994 & -0.5221 & -0.4386 & -0.3667 & -0.0939 & 0.0435 & -0.0729 & $-3.24^{* *}$ & $-5.36^{* *}$ \\
\hline 1995 & 1.2451 & 1.1956 & 0.4085 & 1.9123 & 1.5350 & 0.5097 & $-5.98 * *$ & $-2.33^{*}$ \\
\hline 1996 & 1.4135 & 1.1675 & 0.4634 & 1.9026 & 1.4838 & 0.5227 & $-3.49^{* *}$ & -1.39 \\
\hline 1997 & 0.6654 & 0.8024 & 0.2358 & 1.0693 & 1.0269 & 0.1455 & $-4.13^{* *}$ & 0.52 \\
\hline 1998 & -0.0248 & 0.2784 & -0.0220 & 0.5336 & 0.6478 & 0.0869 & $-3.94^{* *}$ & $-2.96 * *$ \\
\hline 1999 & 1.6160 & 1.3178 & 0.4034 & 1.7471 & 1.1839 & 0.2914 & -0.89 & $2.01^{*}$ \\
\hline
\end{tabular}

**Significant at $1 \%$ level.

*Significant at 5\% level. 


\section{Table 3: Regression Results of Sharpe Ratio on Management and Incentive Fees}

Data is from Tremont TASS (Europe) Limited (TASS). The dependent variable in the regression is Sharpe ratio of each fund; the independent variables are management fee, incentive fee, fund age, and logarithm of fund assets.

Fund of Funds

Hedge Funds

\begin{tabular}{|c|c|c|c|c|c|c|}
\hline variable & estimate & std error & $t$-value & estimate & std error & $t$-value \\
\hline Intercept & -0.6082 & 0.1531 & $-3.97^{* *}$ & -0.9989 & 0.1088 & $-9.18 * *$ \\
\hline Management & -0.0553 & 0.0205 & $-2.70 * *$ & -0.0180 & 0.0133 & -1.35 \\
\hline Incentive & 0.0011 & 0.0020 & 0.57 & 0.0050 & 0.0018 & $2.78 * *$ \\
\hline Fund age & -0.0009 & 0.0004 & $-2.15 *$ & -0.0009 & 0.0003 & $-3.09 * *$ \\
\hline Log(assets) & 0.0578 & 0.0089 & $6.52 * *$ & 0.0730 & 0.0061 & $12.06 * *$ \\
\hline $\mathrm{N}$ & 324 & & & $\mathrm{~N}$ & 1232 & \\
\hline $\mathrm{R}^{2}$ & $17.79 \%$ & & & $\mathrm{R}^{2}$ & $10.61 \%$ & \\
\hline $\operatorname{Adj} R^{2}$ & $16.76 \%$ & & & Adj $R^{2}$ & $10.32 \%$ & \\
\hline
\end{tabular}

**Significant at $1 \%$ level.

*Significant at $5 \%$ level 


\section{Table 4: Example of Positive Incentive Fees Due on Negative Fund of Fund Returns}

In this hypothetical example, a fund of funds is established with $\$ 1 \mathrm{M}$ invested in each of three hedge funds that earn (before fees) $20 \%, 40 \%$ and $-75 \%$. Each of these funds charge an incentive fee of 20 percent above a zero benchmark. For simplicity, none of the funds charge a management fee.

Variable

Hedge Fund 1 Hedge Fund 2 Hedge Fund 3 Fund of Funds

\begin{tabular}{lcccc}
\hline & & & & \\
Start of year (\$M) & $\$ 1.00$ & $\$ 1.00$ & $\$ 1.00$ & $\$ 3.00$ \\
Annual return (before fee) & $20 \%$ & $40 \%$ & $-75 \%$ & $-5 \%$ \\
End of year (\$M) & $\$ 1.20$ & $\$ 1.40$ & $\$ 0.25$ & $\$ 2.85$ \\
Incentive fee (\$M) & $\$ 0.04$ & $\$ 0.08$ & $\$ 0.00$ & $\$ 0.12$ \\
Incentive fee ratio & & & & $4 \%$ \\
Annual return (after fee) & $16 \%$ & $32 \%$ & $-75 \%$ & $-9 \%$ \\
& & & & \\
\hline
\end{tabular}




\section{Table 5: Deadweight Cost Estimates Associated with Not Hedging Fund Incentive Fees}

For every hedge fund included in the March 2000 TASS database including all defunct funds but excluding designated funds of funds we infer before-fee returns on the basis of reported after-fee returns, fee structures and benchmarks reported to TASS for the fund. For each fund we first calculate the magnitude of incentive fees implied by the incentive fee provisions and stated benchmarks, allowing for the highwatermark provision that adjusts benchmarks to require the manager to recoup past losses before an incentive fee is charged. We then compute the Black-Scholes value of the incentive fee contract, based on the contract provisions, current Treasury Bill rate and measure of historical volatility based on the time series of before-fee returns for that fund. The cross-sectional average difference between the ex-post realized incentive fee and the ex-ante cost of hedging that fee we term the average deadweight cost associated with not hedging fund incentive fees. We provide t-values for this quantity.

\begin{tabular}{cccccc}
\hline Year & $\mathrm{N}$ & $\begin{array}{c}\text { Average incentive fee as a } \\
\text { percentage of start of year value }\end{array}$ & $\begin{array}{c}\text { Average cost of } \\
\text { hedging incentive fee }\end{array}$ & $\begin{array}{c}\text { Average } \\
\text { deadweight cost }\end{array}$ & $\mathrm{t}$-value \\
\hline & & & & & \\
1995 & 743 & $4.96 \%$ & $1.81 \%$ & $3.15 \%$ & 5.79 \\
1996 & 816 & $4.87 \%$ & $1.22 \%$ & $3.65 \%$ & 6.03 \\
1997 & 927 & $3.40 \%$ & $1.21 \%$ & $2.19 \%$ & 4.90 \\
1998 & 985 & $3.18 \%$ & $1.11 \%$ & $2.06 \%$ & 4.23 \\
1999 & 828 & $4.99 \%$ & $0.68 \%$ & $4.31 \%$ & 6.55 \\
\hline
\end{tabular}


Fund of funds with one fund 1995-2000

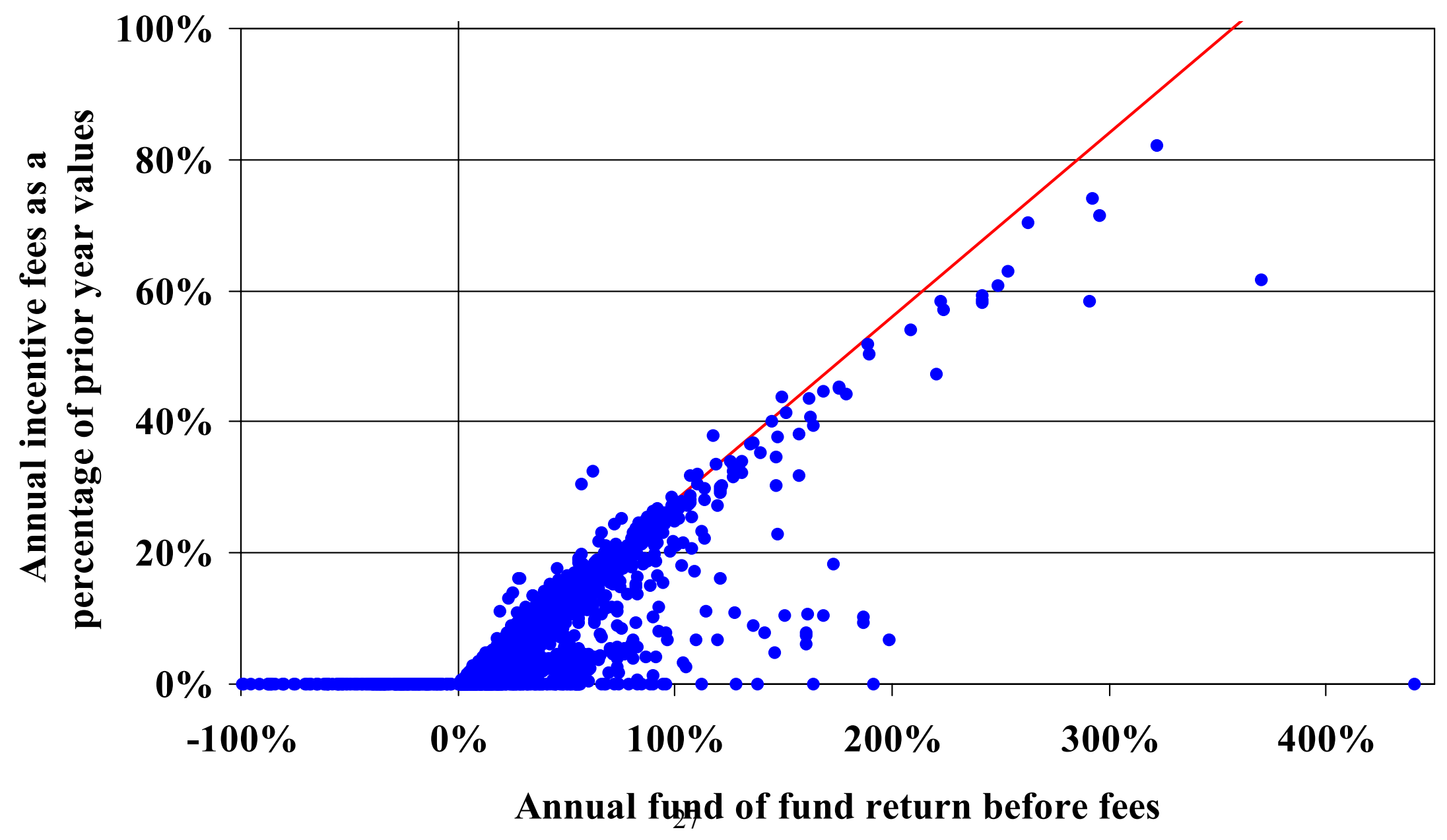


Funds of Funds with five funds 1995-2000

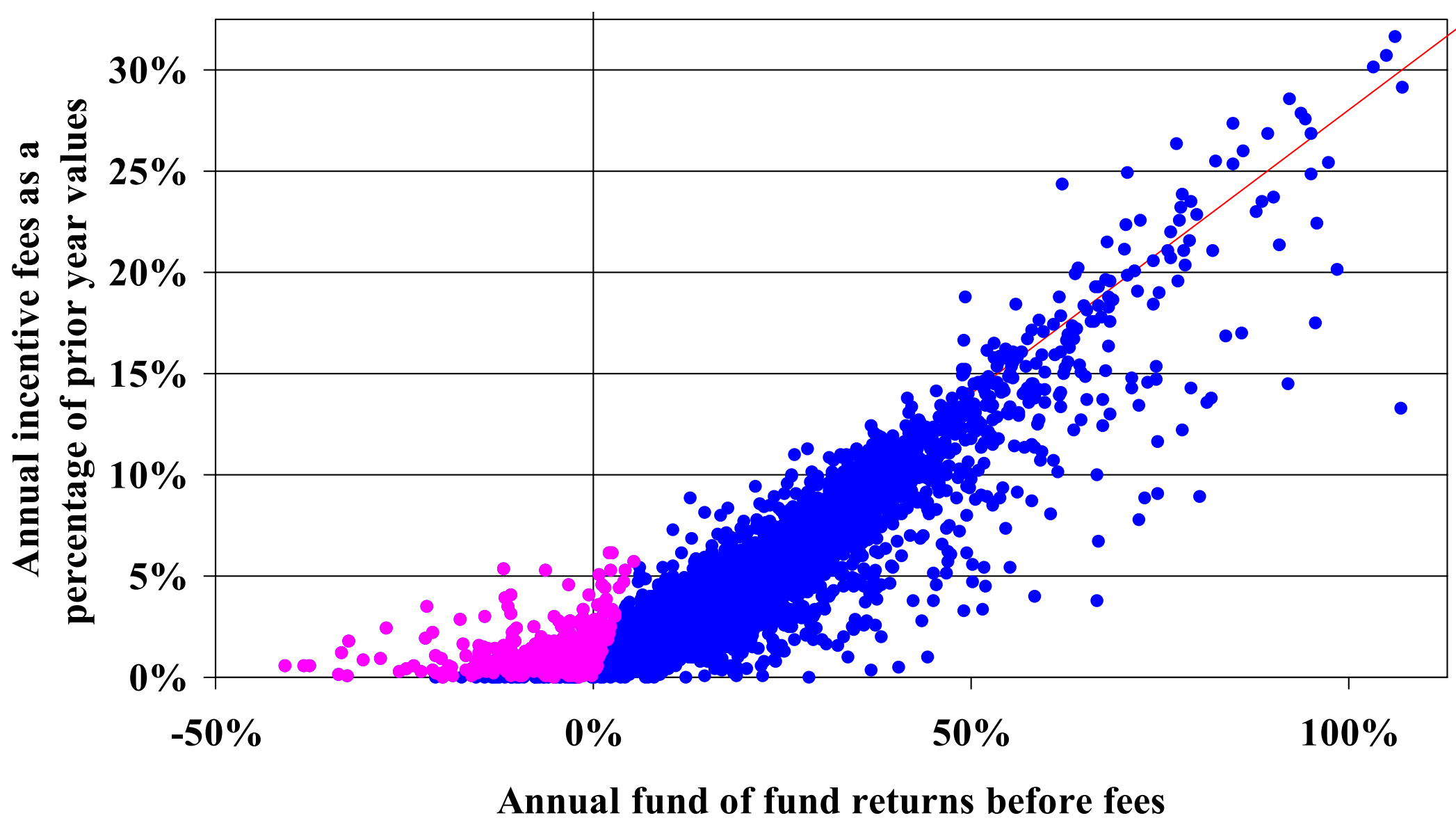


